\title{
Outlaw Bikers and Patched Street Gangs: The Nexus Between Violence and Shadow Economy
}

\section{Author/s: Carl Bradley}

To cite this article: Bradley, C. (2020). Outlaw Bikers and Patched Street Gangs: The Nexus Between Violence and Shadow Economy. National Security Journal.

doi:10.36878/nsj20200201.02

To link to this article: https://doi.org/10.36878/nsj20200201.02

View CrossRef data: https://search.crossref.org/?q=10.36878\%2Fnsj20200201.02 


\title{
OUTLAW BIKERS AND PATCHED STREET GANGS: THE NEXUS BETWEEN VIOLENCE AND SHADOW ECONOMY
}

\author{
Carl Bradley ${ }^{1}$
}

\begin{abstract}
Outlaw bikers, patched street gangs and violence make good headlines and stimulate fierce rhetoric in politics, but does this reflect he re xus be tween gangs, violence and crime? This article analyses gang membership in Aotearoa New Zealand and the nexus between violence and the shadow economy. Patched gangs as a deviant sub-culture have a long history in Aotearoa New Zealand. Drawing on the cultural tenets of the outlaw bikers of North America, outlaw bikers and patched street gangs grew to such an extent that they now have a presence in most towns and cities in Aotearoa New Zealand. One of these tenets is violence and sets patched gangs outside the standard characteristics of hypermasculine groups: violence also makes gangs well-placed to control areas of the shadow economy. This paper seeks to locate gangs in the cultural landscape of Aotearoa New Zealand and interrogate what attracts young men to these groups applying General Strain Theory. This paper al so investigates the te nets of gang culture with a focus on violence and the role it plays in dominating aspects of the shadow economy. Future trends in the face of an increasingly international gang landscape will be considered while issues in obtaining accurate data on gangs will be discussed. It is the author's contention that increased economic inequality will see gang membership rise with a move by some groups to position themselves to further control the drug trade through the threat or use of violence and the utilisation of transnational networks. The author also contends that some gangs will resist such moves towards organised criminal behaviour.
\end{abstract}

Keywords: Outlaw Bikers, Patched Street Gangs, Shadow Economics, Violence, Aotearoa New Zealand

1 Dr Carl Bradley is a Research Fellow with Massey University, Centre for Defence and Security Studies. He researches the changing culture of Outlaw Bikers and Patched Street Gangs as well as indigenous response to colonisation. Carl thanks those who provided feedback of the initial paper given at the 2019 Sociological Association of Aotearoa New Zealand conference. Email contact: C.M.Bradley@massey.ac.nz 


\section{Introduction}

Large patched street gangs and the patched outlaw biker clubs have a long history in Aotearoa New Zealand made up of young males with disproportionate numbers of Māori actively engaging in membership. ${ }^{2}$ These young men follow strict rules of the sub-culture; a factor which will be discussed below. This paper examines the impact of modern social pressures to explain gang membership and their place in the shadow economy. By exploring the tenets of gang membership, particularly violence, this paper seeks to show that by using the threat of violence within the criminal milieu, gangs are well placed to dominate markets within the shadow economy in alternative communities that see violence as a commodity and recognise its power.

Patched gangs are a global phenomenon and there are numerous definitions that cover larger areas of the globe including Canada, Australia and the United Nations (Europol, 2012:1; the National Crime Agency-UK; the Federal Criminal Police Office, BKAGermany). ${ }^{1}$ Gilbert however provides two useful definitions: he states that a gang is 'a structured group (of five or more people) that maintain an exclusive, membership marked by common identifiers and formal rules that supersede the rules of state.'

Of interest to this article is Gilbert's second definition of a criminal gang - 'a structured group (of five or more people) that maintain an exclusive membership marked by common identifiers and formal rules that supersede the rules of state, and an organisational focus on profit through crime. ${ }^{3}$ In the second definition we can see the nexus between gang membership and the focus on crime. These two definitions are useful when determining where a gang sits on the organised crime/gang continuum, concepts we will return to below. Section 98a of the New Zealand Crimes Act 1961 outlines a set of criteria that legally classifies a criminal organisation; these include any group that has 3 or more people, with objectives of either committing serious violence or making money from offences punishable by 4 or more years in jail, as well as knowledge that the gang fits into the above criteria, participation in the gang, and knowledge that their participation contribute to the gang's criminal activity or is reckless to that effect. Both of Gilbert's definitions, and the classifications set out by the Crimes Act, help us locate gangs in the criminal or shadow milieu. But we need to be cautious in making general statements about such a nexus, as in reality any link will be nuanced.

Patched gangs have often been linked to organised crime. Some media, politicians and law enforcement assert that all gangs and gang members are linked to crime and the shadow economy. This is a view most gangs refute. Added to the confusion around such

2 The author accepts that there are marked differences between outlaw biker clubs and patched street gangs. However, when considering the main tenet of violence that is recognised by both groups, and potential criminal activity, this article looks broadly at both groups within this context of patched membership, violence and crime. There is also an understanding by the author that some outlaw bikers reject the label "gang" but it is used here following Jarrod Gilbert's definitions of these sub-cultural groups See Patched: The History of Gangs in New Zealand. (Auckland: Auckland University Press, 2013) p. IX. 
a nexus is that a view either way ignores the nuanced attitudes towards crime by gangs and the role they may play in the shadow economy. Therefore, this article discusses the divergence in opinions, but before this can happen it is prudent to define the shadow economy.

Fleming, Roman and Farrell describe shadow economics as any activity that falls outside the purview of government including conscious efforts to avoid official detection. ${ }^{4}$ It is also referred to as informal, hidden, black, underground, grey, clandestine, illegal and parallel. ${ }^{5}$ Therefore, the shadow economy is the term generally used to describe the alternative mode of capitalism to the legal trade in licit goods and services. The trade in illicit goods and services, while outside the law, runs parallel, effectively a smaller shadow economy to the larger legal economy.

The percentage of income that makes up the shadow economy in the OECD countries is around $17.7 \%$ of the global economy. Within Aotearoa New Zealand the figure for the shadow economy is estimated at $13.6 \% .{ }^{6}$ Given that the national GDP sits at approximately \$US206 billion, ${ }^{7}$ this represents about \$US28 billion of untaxed earnings. While not all business conducted within the shadow economy involves gangs, they compromise an important part of it. Some of this shadow activity is tax evasion or under-the-table transactions and not all of this is associated with the trading in illicit goods and services such as illegal and prescription drugs, debt collection or "taxing" in the gang sense. Fleming, Roman and Farrell do however categorise criminal or irregular activities such as illegally produced goods and services, illicit narcotics services which evade legal reporting requirements as a component of the shadow economy. ${ }^{8}$ To better understand the nexus between some gangs, gang members and crime we must first explore the history of patched gangs in Aotearoa New Zealand.

\section{History of Outlaw Bikers and Patched Street Gangs}

As stated above, patched gangs have existed as a small section of the communities who make up the society of Aotearoa New Zealand, and they have done so for several generations. ${ }^{9}$ Because of social and economic upheaval, young men and women began to create loosely affiliated groups in the 1950s and 1960s. ${ }^{10}$ From the 1960s, and the arrival of the structure and back patch identifier of the Hells Angles, groups in Aotearoa New Zealand began following the hierarchy and symbolic markers of the outlaw biker culture of the United States (US). ${ }^{11}$ The outlaw biker and patched street gang show both the outward symbols of gang membership, and the strict hierarchy of office-bearers and internal enforcers. Regardless of a group being a patched street gang or outlaw biker gang, the back patch remains a territorial marker.

Outlaw bikers and patched street gangs formed in the 1960s and quickly took hold across the country. Such groups established 'Chapters' which acted as the focal points 
for group activities. A Chapter would comprise a president who is elected by various processes, a vice-president, a road captain (for outlaw bikers), as well as a chapter secretary and treasurer. ${ }^{12}$ Following the US, the outlaw bikers and patched street gangs in Aotearoa New Zealand also maintained a position of sergeant at arms or enforcer responsible for discipline within the club and answerable to the president only. Such a position within the gang hierarchy exemplifies the para-military nature of patched gangs and recognises the need to address external aggression from other gangs and potentially the police, while also enforcing club rules and discipline with the threat of violence for transgressors of such rules. The spectre of violence holds currency within the gang milieu and expresses power that has potential benefits for controlling markets in the shadow economy, a point we will return to below.

\section{Patched Gangs Members and Prospects}

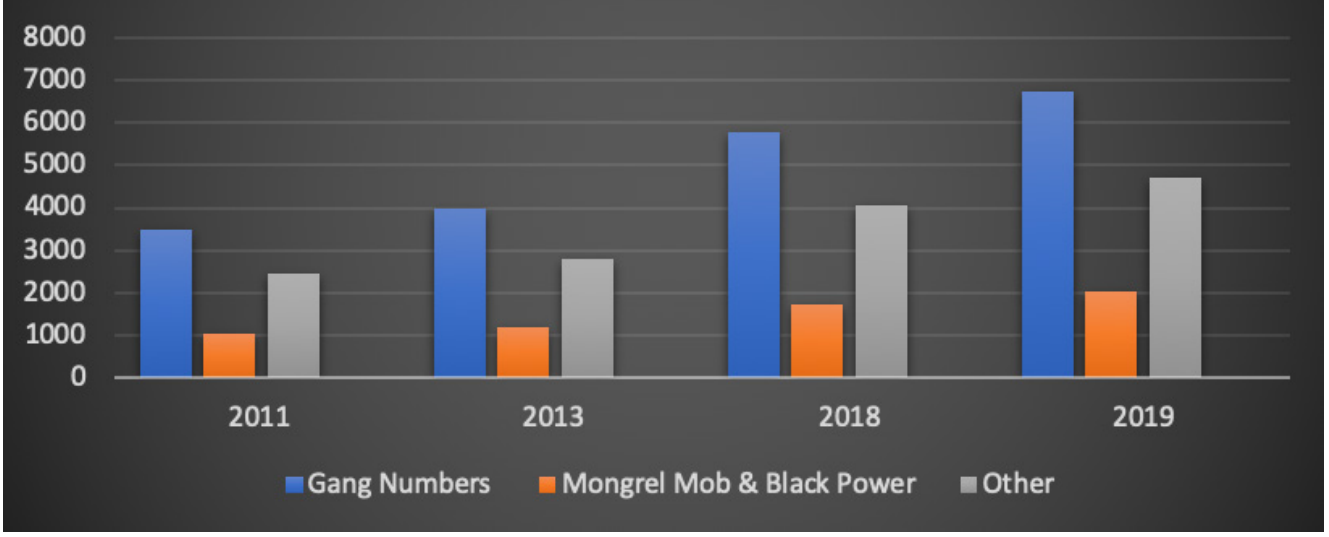

Table 1: (Sources: Minister of Police, 2019, Radio NZ, 2018; NZ Govt, 2014; Taonui \& Newbold, 2011).

As of September 2019, there were 6735 known patched gang members and prospects with reportedly 30 to 40 known gangs in Aotearoa New Zealand. ${ }^{13}$ Gang numbers have risen from 5785 in $2018 ;{ }^{14}$ a drastic increase of gang members since 2011 where the government reported gang membership at $3500 .{ }^{15}$ Such numbers place Aotearoa New Zealand as having one of the largest gang populations per-capita in the OECD, well above Australia (its closest neighbour which has a similar number of gang members). Approximately one third of gang membership in Aotearoa New Zealand sits within the two major patched street gangs, the Mongrel Mob and the Black Power with numbers of the former standing at around 1049 and the latter at 595 as of June $2018 .{ }^{16}$ Given the increasing gang numbers over the past eight years (Table 1), it is prudent to try and determine why this increase is happening and its impact on the shadow economy. 


\section{Reasons for joining}

Why do young people join gangs and potentially engage in criminal and risky behaviour? When considering outlaw bikers and patched street gangs and the reasons for their presence in Aotearoa New Zealand, it is difficult to ignore the impact and arguably negative consequences of neo-liberal politics on society. Gangs have been described as 'fraternities of the dispossessed, the disaffected, the economically deprived and the culturally alienated. ${ }^{17}$ Social scientists and criminologists have long sought to understand why young people join deviant groups such as gangs since the Chicago School of Criminology analysed American urban youth gangs in the early decades of the twentieth century. ${ }^{18}$ In the later decades of the twentieth century, theories such as social learning, sub-cultural theories, and strain or opportunity theory considered the idea of following criminal pathways to attain desired goods or the symbols of success in modern capitalist society. Criminal behaviour can be seen as the result of various influences including social, economic and political factors and the attempts to achieve social and personal success measured in monetary wealth and materialistic cultivation. ${ }^{19}$

In 1937 Robert Merton developed a criminological approach called Strain theory to explain sub-culture and learning. Strain theory looks at the tensions (or strain) between the working and middle-class cultures where blocked opportunities create a sub-culture or alternative cultural system. ${ }^{20}$ His typology of response sets out five adaptations; conformism, innovation, ritualism, retreatism and rebellion. ${ }^{21}$ These five adaptations by members of the society are explained as;

- conformism - the acceptance of culturally designed goals and institutions

- ritualism - the acceptance of culturally designed goals and institutions but with no avenues to attain them going through the motions for their own sake;

- retreatism - the rejection of culturally designed goals and institutions and a retreat from society;

- rebellion- the rejection of culturally designed goals and institutions with the creation of their own goals and institutions, and

- innovation- the acceptance of culturally designed goals but lacking the institutional avenues so adapt. ${ }^{22}$

Strain theory was out of favour as a way to explain deviant behaviour in the 1960s and 1970s, and was seen as too much aligned to the "American dream" analogy. However neo-liberal policies and economic ideology have arguably created an environment where rebellion and innovation can be applied to some patched gang members (and whole chapters) and their participation in the shadow economy. Within the context of strain theory and Robert Merton's five adaptations, we can navigate along some of the issues of modernity and gauge a response through the optic of gang membership, 
deviance and crime. Strain theory can also help us to understand tensions for the development of gangs in Aotearoa New Zealand including the possible criminal dimensions to gang participation in the shadow economy.

In assessing Merton's five adaptations, rebellion and innovation can be applied to explain individual gang membership. Rebellion is the response in which individuals, or in this case potential gang members, substitute their own cultural goals and institutional means in place of the conventional ones. ${ }^{23}$ The initial response by individuals was to rebel against the dominant society and the means of attaining the symbols of success within the society. Whether conscious or not, rebellion would take on meaning to respond to the realisation that the cultural norms and goals for financial success were beyond reach. Anti-social behaviour would constitute one form of outward rebellion and rejection of the mainstream society that represented all that was expected yet denied. The symbols of gang membership, once formed and adopted in the characteristic signifiers such as the back patch, would act as the manifestation of rebellion. In this way, while separated from the mainstream by clear signifiers of behaviour and outward appearance, they would still, through innovative responses remain an economic part of their host communities.

Merton's rebellious response would explain why cliques of young men form small groups in which to become involved in the shadow economy by pursuing crime to attain the material and financial benefits post-industrialised society has to offer. Small group cohesion, combat experience gained from conflict with other groups of young men, and the para-military structures adapted from the outlaw bikers from North America meant that these groups, as they grew in confidence and strength, would move to control the criminal business in the shadow economy. And they would do this through the ability to use or threaten violence. From rebellion some within these groups would innovate to align and gain the financial rewards of contemporary society.

Looking at crime as an alternative reaction to neo-liberal economic ideology of the 1980s and 1990s, Merton's second adaptation, innovation can help explain how some moved to gain access to the benefits of shadow economics. Merton states that innovation comes from those who accept the culturally defined goals of modern society, but they lack the institutional means to achieve them, and as such resort to other innovative means to attain them, in this case crime. ${ }^{24}$ While many within mainstream society accepted such markers of success, some gang members finding the institutional avenues blocked, responded by innovating their response to wealth attainment through alternative means, crime being just one such pathway. ${ }^{25}$ Gangs fit within Merton's typology but before such an innovative response there would have been a rejection of the cultural norms of social behaviour. Suffice to say that gangs, who occupy a place in the shadow economy, show innovative responses to the capitalist system in Aotearoa New Zealand. Violence and 
rebellion align to a desire to attain material wealth available in the shadow economy, itself a social and economic response to neo-liberal capitalism with an alignment to criminal innovation.

General Strain Theory developed by Robert Agnew has been in favour since the 1990s and tends to look at the individual and the different classes rather than the whole structure. ${ }^{26}$ The main types of strain for Agnew consist of goal blockage, noxious or negatively valued stimuli and the inability for whatever reason to satisfy strong desires for money, excitement and masculine status. ${ }^{27}$ It is contented here that while it is important to recognise the role that these more defined strains play on individual decision-making and behaviours, Merton's strain theory has equal relevance in today's environment and should not be dismissed out of hand. Both Merton's adaptations and Agnew's advancement in the form of General Strain Theory, and more individually focused responses, can be applied to explain the reactions of the powerless and such strain wrapped up with the desire for status, respect and power.

For some, the effects of economic and class marginalisation under successive governments and policy decisions suggests that the shadow economy provides a means to earn money in a system dominated by capitalist ideals, albeit in the trade of illicit goods. For some, class exclusion saw moves into counterculture and shadow economics a viable option. While aspects of social and economic dislocation were not the only factors offering reasons for some young people to form and join such groups, who often displayed anti-social or counter-cultural behaviours, unemployment, urbanisation and the loss of social and in some cases parental controls added to the allure of sub-cultural deviant groups like gangs. ${ }^{28}$ Such sub-cultural systems based on economic hardship can be used to explain the existence of gangs and gang membership within a modern liberal democratic society. Patched gangs in Aotearoa New Zealand tend to "proliferate" in lower class areas characterised by high unemployment, low wages, restricted opportunity, boredom, alienation and anomie..$^{29}$

\begin{tabular}{|l|l|l|l|}
\hline Date & Prison Population & Gang population & $\%$ \\
\hline 2011 & 8,547 & 1,555 & 18.1 \\
\hline 2012 & 8,579 & 1,960 & 22.8 \\
\hline 2013 & 8,597 & 2,173 & 25.3 \\
\hline 2014 & 8,606 & 2,283 & 26.5 \\
\hline 2015 & 8,894 & 2,427 & 27.2 \\
\hline 2016 & 9,532 & 2,912 & 30.5 \\
\hline 2017 & 10,261 & 3,367 & 32.8 \\
\hline 2018 & 10,435 & 3,660 & 35.0 \\
\hline 2019 & 9,969 & 3,695 & 37.0 \\
\hline
\end{tabular}

Table 2: (Source: Department of Corrections-2019). ${ }^{3}$

3 Prisoners are identified through various means such as gang tattoos/markings, gang documenta- 
Neo-liberal capitalist ideology and the widening gap in economic equality has placed modern society under considerable stress. Given the increasing numbers of patched gang members and their growing prison population (Table 2), Merton's second adaptation of innovation and the search for status, respect and power can help explain the nexus between gangs and the shadow economy. But what makes such a connection possible?

\section{Tenets of patched gangs and outlaw bikers}

When we appreciate the cultural tenets of outlaw biker and patched street gang culture, we can begin to understand the nexus between some gangs and crime. The tenets of gang culture are the major characteristics that shape the inner structure and attitudes of the patched gang members, but also the outward appearance of the gang. Outlaw biker and patched street gang culture has an outward uniformity in its symbolic markers and perceived anti-social behaviours. Aspects of such behaviours, particularly the "barbarian culture" offences, ${ }^{30}$ are often taken up by politicians and media around election time and can be what shapes public perceptions of the outlaw biker and patched street gangs.

International literature on gangs and gang membership have identified tenets of the outlaw culture ${ }^{31}$ and these can also be applied to the patched street gangs of Aotearoa New Zealand. Before we look at the Aotearoa New Zealand context, we need to list such tenets, with some detail given to the para-military nature of gangs. Such a focus helps explain their ability to control the shadow world and criminal entrepreneurship. The key tenets from the outlaw biker culture include; being a "righteous" biker showing the qualities for toughness and violence; ${ }^{32}$ a strong sense of brotherhood $;{ }^{33}$ military or combat cohesion; $;^{34}$ counter-cultural ideals; ${ }^{35}$ a male dominant society or saloon culture; ${ }^{36}$ and riding large American motorcycles within the context of outlaw bikers gangs and some patched street gangs. ${ }^{37}$ These tenets made their way to Aotearoa New Zealand when Jim Carrico unofficially established the Hells Angels chapter in Auckland in the early 1960s that followed the structure of the Californian Hells Angels. ${ }^{38}$

The idea of a righteous biker is taken from the North American literature on outlaw bikers and can be recognised as having what it takes to be a fully patched member of a gang. This can be applied across the gang cultural landscape where the tenet of brotherhood creates the social bonding based on an understanding of the strict rules that govern small group cohesion and culture. In this environment partying and fighting are attributes that hold currency. In a sense, these tenets form a web of interconnectedness. In social interaction and the pressure of violent confrontation, potential gang members are introduced to the culture and assessed for their suitability for

tion/paraphernalia, information for other agencies, admission to staff, staff observations and intelligence information from other sources (Department of Corrections-2019). 
joining the brotherhood of patched membership..$^{39}$ For Aotearoa New Zealand, usually although not always, the cultural milieu of gang membership has a familial or whanaubased element. ${ }^{40}$

All patched gangs in Aotearoa New Zealand are made up of chapters or clubs based on a regional location within a town or city. These chapters are small, tight units that tend to be of a certain size which is important for small group cohesion in fighting other groups. ${ }^{41}$ Such local and territorial imperatives shape the gang map of Aotearoa New Zealand and this has an impact on the shadow economy if different groups compete for markets in the same area. The defence of territory does however, go beyond the control of markets and such territorial competition pre-dates patched gang involvement in crime. ${ }^{42}$ Fighting is linked to territorial defence and often paramilitary in nature and structure ${ }^{43}$ and the patch is central to the ideals of combat cohesion and violence. Violence is the most significant tenet when considering the potential for some gang members to participate in the shadow economy. Violence is both the means and expression of power.

\section{Violence and the Shadow}

The nexus between gang membership and crime took significant steps towards more organised orientations in the 1970s when convicted gang members were placed in correctional facilities that housed serious criminals. ${ }^{44}$ Any scan of the public or government discussion on gangs shows that violence, or the threat of it, makes good media fodder and even better political rhetoric. ${ }^{45}$ However, beyond such rhetoric it is the threat of violence and the combat cohesion seen in gangs that has very real currency in the shadow world. Those who are not in the sphere of gang activity need not worry too much about this violence ${ }^{46}$ However, those who move within the orbit of gang activity and the shadow economy do need to carefully navigate this space. It is in the shadow economy where the potential to reinforce territorial markets with violence occurs, and the difference in gangs and chapters will rise. The use, or threat of violence means that gangs which are organised in para-military hierarchies, can move easily in the world of illicit business - the shadow economy. Territorial competition could explain the rise in reported or observed inter-gang tensions that are being uploaded onto social media sites ${ }^{47}$ Such behaviour has historically remained hidden from the general public.

The utility of controlling markets in the shadow economy means that financial benefits can be considerable. It has been observed that bikers love a monopoly and while discussing this control in the context of the criminal business world a monopoly over violence can also be applied to some degree. ${ }^{48}$ One of the main characteristics of state power is the monopoly of the threat or use of force. ${ }^{49}$ Gangs, with their para-military structure and experience in territorial defence and inter-gang conflict, are well placed to monopolise the threat or use of force within the shadow economy and other people 
involved in it. But just like any state which must consider the impact and consequences of the use of force, gangs must also make decisions about enforcing their rules and controlling their markets with a balanced and realistic pragmatism. Like the faceless authority of state violence or maintaining law and order, gang violence, when placed in the context of shadow economics, is less personal and much more about business. ${ }^{50}$

The freedom or counterculture seen in gangs is different from other counter-culture movements in that they display deliberately challenging anti-social behaviours that are reinforced with para-military precision and discipline. Controlled aggression or the threat of it is usually avoided in public and is not good for business. ${ }^{51}$ Violence may however be unavoidable for a gang member because of the stock placed in one's reputation or status and that of the gangs. Gang-related violence in Australia makes up 0.6\% of all crime with bikers responsible for $0.3 \% .{ }^{52}$ Information on gang-related crime in Aotearoa New Zealand is difficult to attain with an Official Information Act request for such data in 2019 being answered by the response that it is not collected by the Ministry of Justice. Gilbert alleges that the data he has seen does not fit the narrative of the Government that gangs are involved in crime to the level that is claimed. ${ }^{53}$ This said, such a mix of counter-cultural attitudes, anti-social behaviours and para-military discipline means that gangs are well-placed to stake a claim of control in the world of shadow economics. Given that many markets in illicit goods are predatory, violence that is also predatory has a role to play in shadow economics. ${ }^{54}$

\section{Control and the code of silence}

When considering the shadow economy, gangs and others work outside of legal protection found in the mainstream economic environment. The way to control the shadow economic milieu is to establish strict rules around who you talk to. Within secret societies and criminal organisations there are normally codes of silence that are clearly communicated to members, both within the group or on the fringes, around who you can and cannot talk to. ${ }^{55}$ Indeed, criminal organisations demand a degree of "silence" to operate illegally, particularly when it comes to other criminal organisations or law enforcement. Such an imperative to maintain a code of silence is manifest in ideals of loyalty, but such loyalty is often reinforced by the threat of violence. For Aotearoa New Zealand there exists an attitude of silence colloquially known as "narking". ${ }^{56}$ The term narking is prison slang for talking to the prison authorities and use of the term has moved beyond the prisons.

Such rules around silence allows secretive or criminal groups to operate with limited fear from the possibility of the community reporting crime to the police. ${ }^{57}$ Such attitudes often reflect the communities' attitudes towards law enforcement and are particularly strong in neighbourhoods that have a strong criminal element. To this end, communities with a stake in the shadow economy may be less likely to report crime because of the code of silence, and as a result may not reflect national crime statistics. Such a culture of silence 
can also lead to gangs establishing themselves as their own local law enforcement if a vacuum exists or where the community feels it cannot rely on police. ${ }^{58}$ Codes of silence within the community can be enforced with violence as seen with Chris Crean in New Plymouth who agreed to give evidence against the Black Power. ${ }^{59}$ Witnessing a gang confrontation in March 1996, Crean, who had no association to the gang milieu in Taranaki, was shot and killed by the Black Power to prevent his testifying. ${ }^{60}$ To this end violence acts as a sub-cultural construct to control communication within the shadow milieu. Indeed, von Lamp sees violence as a functional alternative to trust. ${ }^{61}$

Mechanisms of trust, silence and violence potentially work well for some outlaw bikers or patched street gangs to establish and control markets in the shadow economy. Such tenets can create an image of organised criminality. Barker recognises the situation where those members who commit serious crime are arguably doing so with the consent or complicity of other members not involved in any crime whatsoever ${ }^{62}$ As such, these individuals represent semi-autonomous actors involved in individual business (rather than as representatives of their gang) but using their gang membership as leverage in the shadow economy. ${ }^{63}$ A senior member of the Hells Angels in the United States believed during the late 1960s that the patch was valuable for entering the shadow economy ${ }^{64}$ The gang conservative/radical continuum, ${ }^{65}$ identifies the position a gang sits in the criminal continuum to clarify the question of whether outlaw bikers constitute organisations of criminals or criminal organisations. Simply put, at one end are the conservative bikers that may partake in offences such as violence, drunk and disorderly and small-time drug offences while at the other more radical end are those involved in extortion, serious drug offences, and money laundering. ${ }^{66}$ In this situation, the club will be measured along this continuum by the actions of the members behaviour, whether endorsed by the whole club or not. Quinn and Koch also ask the question of whether outlaw bikers and their crimes represent individual versus chapter "business". ${ }^{67}$

The conservative/radical continuum accepts some level of criminality within these organisations. While law enforcement generally views this as a legitimate acknowledgement, some patched street gangs and outlaw bikers in Aotearoa New Zealand would challenge such a view. ${ }^{68}$ The main question that is asked in this situation is whether all patched members in Aotearoa New Zealand are involved in crime? A more appropriate way of measuring the criminal level of a patched street gang or outlaw biker chapter, given Quinn and Koch's question of individual or club business, can be applied through this conservative/radical continuum.

Such issues of measuring the nexus between gangs and crime raises questions about the accuracy of data and other information that is available." A quick scan of media alerts involving gangs and crime, while unscientific, highlight certain groups that are continually attracting police attention or are before the courts. The Head Hunters, the Rebels MC and the recently established Comancheros all seem to fit the criminal outlaw motorcycle club typology set out by Barker. ${ }^{69}$ The patched street gangs appear to 
take up a lot of media attention but detailed analysis of all the media reporting and court records would be needed to provide an accurate and informative picture of where patched gangs in Aotearoa New Zealand fit within Barkers typology. When Department of Corrections data in Aotearoa New Zealand is analysed, there is a clear picture of gang members listed among the national prison population (see Table 3). What is also evident is that gang numbers in prison are increasing. Such data does need to be analysed to determine which patched gangs make up the prison population and what crimes saw them imprisoned. The Department of Corrections are unusual in New Zealand with their ability to collect and supply data on outlaw bikers and patched street gangs. However, faced with not being able to access comparable data from other government departments on gangs beyond Corrections, researchers and policy makers risk making assessments or providing policy advice that lacks understanding of patched gangs in Aotearoa New Zealand missing the nuances of the gang/crime nexus.

\section{NZ National Prison and Gang Populations 2011 to 2019}

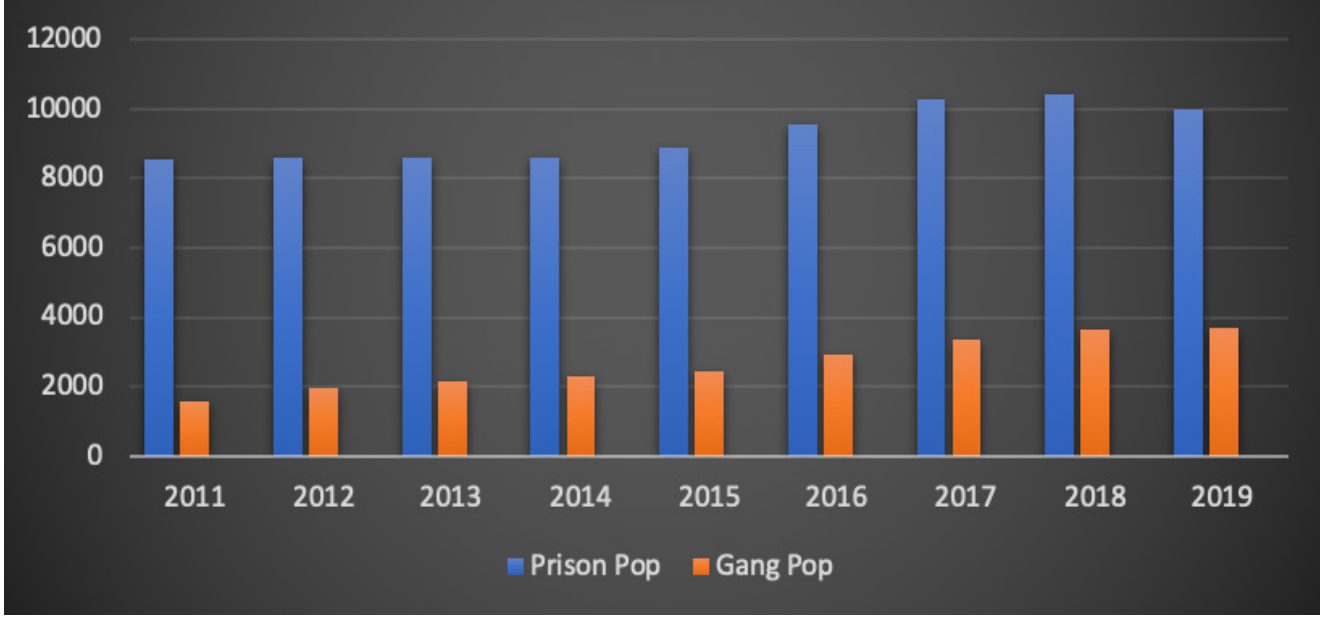

Table 3: (Source: Department of Corrections-2019).

Further research and access to criminal conviction data or police intelligence on outlaw bikers and patched street gangs in Aotearoa New Zealand will allow for some deeper understanding than currently exists around the position patched gangs hold in the shadow economy. Such analysis on outlaw bikers has been done in the Netherlands by Blokland et al in locating where each club sits on Barkers conservative/radical continuum. ${ }^{70}$ However, Blokland et al do provide a caveat that such an approach can be problematic given the fact that much crime is underreported. ${ }^{71} \mathrm{~A}$ recent article by Lauchs applied a scientific approach to analysing court documents involving the Finks MC in 
Queensland Australia, ${ }^{72}$ while a second article by Lauchs and Staines applied a quantitative analysis of data in Queensland of the criminal records of outlaw bikers who participate in serious criminal behaviour. ${ }^{73}$ In their conclusions, it became clear that triangulating media reports, court records and the Queensland government's documents attempts to classify Outlaw bikers as criminal organisations was insightful. This demonstrates that such groups, while falling within the conservative spectrum of criminal behaviour, fail to occupy the more radical spectrum of organised criminal offending. Such articles provide models of analysis that, given the availability of data, can be applied to patched gangs in Aotearoa New Zealand and their involvement in crime.

\section{Future Trends: Gangs and crime}

At the time of writing, Aotearoa New Zealand is going through the global uncertainty with serious economic implications presented with the COVID19 virus. Such a situation has moved the media and political focus away from discussion of outlaw bikers and patched street gangs. But these groups will not be going away and with this comes advantages and disadvantages. In a recent article by Jarrod Gilbert and Ben Elley, they point out that the rise of on-line Alt-Right groups are not coming out of the traditionally lower middle class, but a group which have slowly seen their opportunities of economic and social success shrink. ${ }^{74}$ While they argue that the older skinhead groups came out of the mainly disaffected white working class, ${ }^{75}$ the outlaw bikers and patched street gangs have traditionally drawn its members from the working class, working poor and unemployed. With the expected economic downturn that has been predicted in the face of the COVID19 virus it will be the lower socio-economic groups who feel the full impact. It may well be that, as argued above, such strains and tension will force people to innovate to see themselves and their families long-term through the crisis that is unfolding. Despite the current lockdown, crime may rise as the supply chains become further stretched and outlaw bikers and patched street gangs extend their reach into the shadow economy of the black market. The future does not look good for the lower socio-economic groups long-term either and alternative social systems may come to the fore.

An important factor to this dynamic is the pro-social role such groups already play within their communities. Recently, the Mongrel Mob in Waikato, the Kingdom, have stated their departure from the broader Mob confederation and sought to improve the lives of their members and family and portray a pro-social agenda. This has been a twoyear process with media paying attention to them after they were reportedly asked to protect Mosques in the Hamilton region after the attacks in Christchurch in 2019. Two things happened. There was the usual public scepticism and expectations demanded by the police; and an increased engagement by the Mongrel Mob Kingdom leaders with the media, police and politicians (to the extent that Louise Hutchinson was employed as the Kingdom's public relations spokesperson). 
Perhaps moves by this group has been driven by a social need lacking in the current system that has added to the factors drawing young men into the gangs. What is clear when history is considered is that past moves by law enforcement and politicians to tackle the issues of gangs has failed to have any lasting effect. Legal responses to recruitment and attempts by local bodies such as the Whanganui District Council to prohibit wearing gang insignia in September 2009 and more recently, have come to very little. ${ }^{76}$ Such moves were resisted by the Hells Angels MC on 30 July 2010 and other than further anti-patch wearing legislation such as in Government buildings and hospitals, ${ }^{77}$ nothing has changed. Indeed, gang numbers, be they outlaw bikers or patched street gangs, have steadily increased and become more noticeable. ${ }^{78}$

In late 2019, the Leader of the opposition National Party, Simon Bridges, made a speech about developing a special police unit similar to the Australian Taskforce Raptor. ${ }^{79}$ There already exists several specialist units within NZ Police force that are heavily armed and who can respond to heightened situations. Bridges "Taskforce Raptor" would be like using a sledgehammer to crack a ball-bearing, a futile and ineffective activity for all involved. Existing liaisons between local police and the outlaw biker and patched street gang communities have a longer history of success in dealing with the complexities of these sub-cultural groups. ${ }^{80}$ Bridges approach could seriously jeopardise these long-standing relationships that, from a policing viewpoint show some understanding of the nuances of gang/community dynamics. As stated above, history has shown that governments who have tried to tackle outlaw bikers or patched street gangs through legislation and law enforcement strategies have had little impact on patched membership and tends to affect the communities, families and children associated with gang members instead. Such targeting can also result in the criminalisation of whole communities and goes against the basic principles of community crime prevention of providing opportunities to re-socialise offenders and fostering healthy communities and peer group activities. ${ }^{81}$

With the shifting landscape seen in the arrival of Australian-based outlaw bikers, ${ }^{82}$ there is an urgency to understand the current situation and what that means for the nexus between outlaw bikers, patched street gangs and crime. Warnings have come from crime prevention measures in the Netherlands by labelling all 3-piece patched outlaw bikers as organised crime groups is problematic ${ }^{83}$ Using Barkers conservative/radical continuum can be useful in measuring outlaw biker and patched street gang participation in the shadow economy in Aotearoa New Zealand, but there needs to be reliable data and analysis to support such measuring and to fully appreciate this environment to develop meaningful and lasting approaches to the nexus between patched gangs and crime. If Aotearoa New Zealand is serious about dealing with the gang issue and the nexus between outlaw bikers, patched street gangs and crime then there needs to be greater access to government data on these sub-cultural groups to fully assess the role they play in crime in Aotearoa New Zealand. Barker's continuum is a useful tool when 
sufficient data is available. Restrictions from government agencies can be problematic for researchers in this space to create a clear picture of outlaw bikers and patched street gangs.

\section{Conclusion}

Violence allows patched gangs and gang members to engage in, or take over, certain areas of the shadow economy. However, there are some questions about whether this nexus between gangs and crime is the same for all groups classified as patched gangs. There needs to be better access to government data on the nexus between patched gangs and crime and a more thorough analysis of court documents as seen in Europe and Australia. Further research can stimulate discussion to identify the nuances of patched gangs and where they sit within the shadow economy. Rising numbers in gang membership and the growing gap in social and economic inequality is arguably an environment that creates both push and pull factors in the decision-making processes of young men from the working class to join patched gangs. Given the current uncertainties around the economic stability in the face of COVID-19, there needs to be a better long-term strategy in engaging outlaw bikers and patched street gangs and the role they play in their communities. While the growing numbers of patched members in prison suggests a link between gangs and crime, other government departments can provide data that can help measure such assertions from government and some commentators that all gangs are organised criminal groups, a label most outlaw bikers and patched gangs refute. While the Department of Corrections has provided data on the numbers of patched members in prison, a deeper analysis needs to be conducted to determine which groups are being imprisoned, while further a survey of court documents may also add more information about what crimes patched gang members are being imprisoned for. As it stands, outlaw bikers and patched street gang members and their role in the shadow economy is nuanced and there are too many variables to make a confident statement on the extent to which these groups are organised criminal organisations. While violence is and will be a central tenet of these sub-cultural groups in Aotearoa New Zealand, more research will increase the awareness of the nexus between outlaw bikers, patched street gangs and crime.

\footnotetext{
1 Thomas Barker, The Outlaw Biker Legacy of Violence. (New York, Routledge, 2018) pp.23, 24, 27,31 .

2 Gilbert, Patched p.IX.

3 Gilbert, Patched p.IX.

4 Matthew H. Fleming, John Roman \& Graham Farrell, "The Shadow Economy," Journal of International Affairs, (2000), p.387.

5 Fleming et al, p.387.
} 
6 Friedrich Schneider, "Size and Development of the Shadow Economy of 31 European and 5 other OECD Countries from 2003 to 2012: Some New Facts," 2011. Available at ShadEc31_december 2011. doc

7 www.stats.govt.nz.

8 Fleming et al, p.387.

9 Carl Bradley, "Outlaw Motorcycle Clubs, Organised Crime and National Security" in Wil Hoverd, Nick Nelson \& Carl Bradley, eds. New Zealand National Security: Challenges, Trends and Issues. (Palmerston North: Massey University Press, 2017) pp.272-288.

10 Rawiri Taonui \& Greg Newbold, "Māori Gangs" in Tracey McIntosh \& Malcolm Mulholland, eds. Māori and Social Issues, (Wellington: Huia Publishers, 2011), pp.209, 211. Glenys Dennehy \& Greg Newbold, The Girls in the Gang, (Auckland, Reed Publishing 2001), p.161.

11 Gilbert, Patched p. 31. Dennehy \& Newbold, Girls, p.165.

12 Taonui \& Newbold, "Māori Gangs," p. 211. Dennehy \& Newbold, Girls, p.166.

13 New Zealand Ministry of Police, 2019. "Insight: Future of Gangs," Radio New Zealand, 10 June 2018.

14 “Insight: Future of Gangs," Radio New Zealand, 10 June 2018.

15 Taonui \& Newbold, "Māori Gangs," p.209.

16 "Insight: Future of Gangs," Radio New Zealand, 10 June 2018.

17 Taonui \& Newbold, "Māori Gangs," p.210.

18 Roger Hopkins Burke, An Introduction to Criminological Theory, (London, Routledge 2019), p.143.

19 Mark Lauchs, Andy Bain, \& Peter Bell, Outlaw Motorcycle Gangs: A Theoretical Perspective. (Basingstoke: Palgrave MacMillan 2015), pp.41, 43, 48.

20 Robert Merton, “Social Structure and Anomie," American Sociological Review, (1938), pp.672-682. Lauchs et al, p.45. White, Haines \& Asquith, Crime, p.84.

21 Merton, Social Structure, p. 676; Hopkin Burke, An Introduction, pp. 146-148; Peter Joyce, Criminology and Crime, (New Zealand: Routledge 2018), pp. 21-22; White, Haines \& Asquith, Crime, p. 83.

22 Hopkins Burke, An Introduction, pp.146-148; White, Haines \& Asquith, Crime, p. 83. Lauchs et al, p.43.

23 White, Haines \& Asquith, Crime, p.83.

24 Hopkins Burke, An Introduction, pp.147; White, Haines \& Asquith, Crime, p. 83. Lauchs et al, pp.43-44.

25 Lauchs et al, p. 45,;Taonui \& Newbold, "Māori Gangs," p.209.

26 Robert Agnew, "Foundations of General Strain Theory of Crime and Delinquency," Criminology, (2000), pp.47-87.

27 Hopkins Burke, An Introduction, p.152.

28 Gilbert, Patched, p. 292, 293. Tuhoe Isaac with Bradford Haami, True Red, The life of an ex-Mongrel Mob Gang Leader, (Pukekohe: True Red, 2007), pp.22, 23, 34.

29 Dennehy \& Newbold, Girls, p.68.

30 See Carl Bradley, "Outlaw Bikers, Methamphetamine and Cultural Change," International Journal of Interdisciplinary Social Science Studies, (2018); Lauchs et al. James Quinn and D. Shane Koch, "The nature of criminality within one-percent motorcycle clubs," Deviant Behaviour 24 (3) (2003).

31 Bradley, Outlaw Motorcycle Clubs, p.275, Barker, The Outlaw Biker; Arthur Veno, The Brotherhoods: Inside the Outlaw Motorcycle Gangs, (Crows Nest: Allen \& Unwin 2012), p.93.

32 Barker, The Outlaw Biker, p.17.

33 Gilbert, Patched, p.199.

34 Bradley, Outlaw Motorcycle Clubs, p. 275, Daniel Wolf, The Rebels: A Brotherhood of Outlaw Bikers, (Toronto: University of Toronto press 1991), p.25.

35 Veno, The Brotherhoods, pp. 270, 271; Tim Shadbolt, Bullshit and Jellybeans, (Wellington: A. Taylor, 1971), p.82.

36 Lauchs et al; Veno, The Brotherhoods, see chapter 9. 
37 Veno, The Brotherhoods, p.106.

38 Dennehy \& Newbold, Girls, p. 165; Yves Lavigne, Hell's Angels: Three can keep a Secret if Two are Dead, (Toronto: Carol Publishing Group 1996), pp.61-62.

39 Bradley, Outlaw Bikers, p.7.

40 Bradley, Outlaw Motorcycle Clubs, p.275.

41 Bradley, Outlaw Motorcycle Clubs, p. 275; Daniel Wolf, The Rebels: A Brotherhood of Outlaw Bikers, (Toronto: University of Toronto press 1991), p.25.

42 See Isaac, Red. Gilbert, Patched, pp.71-88.

43 Veno, The Brotherhoods, p.145.

44 Gilbert, Patched, pp.90-91, Dennehy \& Newbold, Girls, p.171.

45 "Deported bikie outlaws are threatening to inflame gang violence in small town NZ," 21 July 2019, Stuff. Available at https://www.stuff.co.nz/national/crime/113545350/deported-bikie-outlaws-are-threatening-to-inflame-gang-violence-in-small-town-nz. "Black Power member admits role in Taranaki gang attack but denies intent", Taranaki Daily News, 13 June 2019. Available at https://www.stuff.co.nz/ taranaki-daily-news/news/113466708/black-power-member-admits-role-in-taranaki-gang-attack-but-denies-intent.

46 Gilbert, Patched, p.202.

47 "Gang fight caught on video in Tokoroa street goes viral," New Zealand Herald, 13 February 2019. Available at https://www.nzherald.co.nz/nz/news/article.cfm?c id=1\&objectid=12203026. "Black Power member admits role in Taranaki gang attack but denies intent," Taranaki Daily News, 13 June 2019. Available at https://www.stuff.co.nz/taranaki-daily-news/news/113466708/black-power-member-admits-role-in-taranaki-gang-attack-but-denies-intent. "Stolen patch mocked online before Stokes Valley gang brawl," Stuff, 19 March 2019. Available at https://www.stuff.co.nz/national/crime/110582125/ stolen-patch-mocked-online-sparked-stokes-valley-gang-brawl. "Large gang fight sees police swoop on 'volatile' situation in Hutt Valley," Stuff, 14 January 2019. Available at https://www.stuff.co.nz/national/ crime/109900067/reports-of-gang-fight-in-stokes-valley.

48 Ross Coulthart \& Duncan McNab, Dead Man Running: An Insider's Story on one of the World's Most Feared Outlaw Motorcycle Gangs...The Bandidos, (Crows Nest: Allen \& Unwin, 2008), p.31.

49 M. Hamilton. \& M. Hirszowicz, Class and Inequality: Comparative Perspectives, (Hemel Hempstead, Harvester Wheatsheaf, 1991), p.75.

50 Coulthart \& McNab, Dead Man, p.31.

51 Clive Small \& Tom Gilling, Blood Money: Bikies, Terrorists and Middle Eastern Gangs, (Sydney: Allen \& Unwin, 2011), p.201.

52 Adam Shand, Outlaws: The Truth About Australian Bikers, (Sydney: Allen \& Unwin, 2011), p.243.

53 "Insight: Future of Gangs", Radio New Zealand, 10 June 2018.

54 Coulthart \& McNab, Dead Man, p.57.

55 James Morton \& Susanna Lobez, Gangland Australia, (Melbourne: Melbourne University Press, 2014), pp. 279, 280; Dennehy \& Newbold, Girls, p. 98-100; Wolf, The Rebels, 1993.

56 Davis Haslett, Riding the Margins: International Media and the Construction of a Generic Outlaw Biker Identity in the South Island of New Zealand, circa 1950-1975, unpublished Master of Arts thesis (Christchurch: University of Canterbury, 2007), p.126.

57 Gilbert, Patched, see pp.199-203.

58 Morton \& Lobez, Gangland p.281.

59 Gilbert, Patched, p.201.

60 Gilbert, Patched, p.201.

61 Klaus von Lampe, Organized Crime: Analyzing Illegal Activities, Criminal Structures and Extra-legal Governance, (Los Angeles: Sage, 2016), p.121.

62 Thomas Barker, Biker gangs and Organized Crime, (Newark: Matthew Bender and Company, Inc., 2007).

63 Taonui and Newbold, "Māori Gangs," p. 221, Dennehy \& Newbold, Girls, pp.190, 121, 122. 
64 George Wethern \& Vincent Colnett, A Wayward Angel: The Full Story of the Hells Angels, (Lyon Press, 2008), pp.38-41.

65 Bradley, Outlaw Bikers, p. 8, Thomas Barker, Outlaw Motorcycle Gangs as Organized Crime Groups, (Richmond: Eastern Kentucky University, 2014), p.13.

66 Lauchs, Are Outlaws?, p. 293.

67 Quinn and Koch, The nature of criminality p.283.

68 Bill Payne \& Peter Quinn, Staunch: Inside the Gangs, (Auckland: Reed Books, 1991), p.57.

69 "Australian biker gang the Comancheros building strength in NZ," 29 December 2017, Newshub NZ . Available at https://www.newshub.co.nz/home/new-zealand/2017/12/australian-biker-gang-the-comancheros-building-strength-in-nz.html. "Methamphetamine and gun found at Rebels Motorcycle Club's Christchurch HQ," Stuff, 14 April 2016. Available at https://www.stuff.co.nz/the-press/news/78931631/ methamphetamine-and-gun-found-at-rebels-motorcycle-clubs-christchurch-hq "Rebels Motorcycle Club quits Christchurch headquarters". Stuff June 18, 2016. Stuff Available at https://www.stuff.co.nz/national/ crime/81196483/rebels-motorcycle-club-quits-christchurch-headquarters. "Police raid Rebels Motorcycle Club's temporary base in Christchurch," Stuff, 22 July 2016. Available at https://www.stuff.co.nz/ national/crime/82372644/police-raid-rebels-motorcycle-clubs-temporary-base. "Rebels motorcycle gang shut down with community help," 17 June 2016, New Zealand Police. "Rebels gang dealt another blow," 1 September 2011, New Zealand Police. "Cut the head off the snake: Bold plan to combat NZ's gangs," 20 May 2018, Newstalk ZB. Available at https://www.newstalkzb.co.nz/news/crime/cut-the-head-off-thesnake-bold-plan-to-combat-nzs-gangs/. "What risk do Comancheros gang members pose to New Zealand?," 16 March 2018, Newshub. Available at https://www.newshub.co.nz/home/new-zealand/2018/03/ what-risk-do-comancheros-gang-members-pose-to-new-zealand.html.

70 Blokland et al, "Outlaw Bikers in the Netherlands: Clubs, Social Criminals Organizations or Gangs?," in Andy Bain \& Mark Lauchs eds, Understanding the Outlaw Motorcycle Gangs: International Perspectives, (Durham: Carolina Academic Press, 2017), pp.91-114.

71 Blokland et al, Outlaw Bikers, p.109.

72 Mark Lauchs. "Are Outlaw Motorcycle Gangs Organized Crime Groups? An Analysis of the Finks MC," Deviant Behaviour, (2018), pp.287-300.

73 Mark Lauchs, M \& Zoe Staines, "An analysis of outlaw motorcycle gang crime: are bikers organised criminals?," Global Crime, (2019), pp.69-89.

74 Jarrod Gilbert \& Ben Elley, "Shaved heads and sonnenrads: comparative white supremacist skinheads and the alt-right in New Zealand," Kōtuitui: New Zealand Journal of Social Science Online (2020), p.8.

75 Gilbert \& Elley, "Shaved Heads," p.8.

76 Julie Ayling \& Roderic Broadbent, "Organized Crime Control in Australia and New Zealand" in Oxford Handbook of Organized Crime, (Oxford: Oxford University Press, 2014), pp. 625, 626.

77 Ayling \& Broadbent, Organized Crime, p.627, 629.

78 New Zealand Ministry of Police, 2019.

79 "Simon Bridges defends Strikeforce Raptor war on gangs Plan," 27 November 2019, Newshub. Available at https://www.newshub.co.nz/home/politics/2019/11/simon-bridges-defends-strike-force-raptor-war-on-gangs-plan.html.

80 Haslett, Riding. See Chapter Six.

81 White, Haines \& Asquith, Crime, p.76.

82 "NZ street gangs are facing an influx of Australian outlaw bikers," New Zealand Herald, 8 February 2019. Available at https://www.nzherald.co.n/news/article.cfm?c_id=1\&objectid=12201583.

83 Blokland et al, Outlaw Bikers, pp.10 